\title{
A Rapid and Efficient Method for Purifying High Quality Total RNA from Peaches (Prunus persica) for Functional Genomics Analyses
}

\author{
LEE MEISEL ${ }^{1,2,3}$, BEATRIZ FONSECA ${ }^{2}$, SUSANA GONZÁLEZ², RICARDO BAEZA- \\ YATES $^{4}$, VERONICA CAMBIAZO $^{5}$, REINALDO CAMPOS $^{6}$, MAURICIO $^{2}$ \\ GONZALEZ $^{5}$, ARIEL ORELLANA ${ }^{1,2,3}$, JULIO RETAMALES ${ }^{6,7}$ and HERMAN \\ SILVA $^{1,2,3^{*}}$
}

\author{
${ }^{1}$ Millenium Nucleus in Plant Cell Biology P02-009-F. \\ ${ }^{2}$ Laboratorio de Genética Molecular Vegetal, Departamento de Biología, Facultad de Ciencias, Universidad \\ de Chile. \\ ${ }^{3}$ Centro de Biotecnología Vegetal, Facultad de Ecología y Recursos Naturales, Universidad Andrés Bello, \\ Santiago, Chile \\ ${ }^{4}$ Facultad de Ciencias Físicas y Matemáticas, Universidad de Chile, Santiago, Chile \\ ${ }^{5}$ INTA, Universidad de Chile, Santiago, Chile \\ ${ }^{6}$ INIA La Platina, Santiago, Chile \\ ${ }^{7}$ Facultad de Ciencias Agronómicas, Universidad de Chile, Santiago, Chile
}

\begin{abstract}
Prunus persica has been proposed as a genomic model for deciduous trees and the Rosaceae family. Optimized protocols for RNA isolation are necessary to further advance studies in this model species such that functional genomics analyses may be performed. Here we present an optimized protocol to rapidly and efficiently purify high quality total RNA from peach fruits (Prunus persica). Isolating high-quality RNA from fruit tissue is often difficult due to large quantities of polysaccharides and polyphenolic compounds that accumulate in this tissue and co-purify with the RNA. Here we demonstrate that a modified version of the method used to isolate RNA from pine trees and the woody plant Cinnamomun tenuipilum is ideal for isolating high quality RNA from the fruits of Prunus persica. This RNA may be used for many functional genomic based experiments such as RT-PCR and the construction of large-insert cDNA libraries.
\end{abstract}

Key terms: cDNA library, fruit, fruit trees, functional genomics, peach, polysaccharides, Prunus persica, RNA isolation, Rosaceae, RT-PCR.

Abbreviations: DEPC: diethyl pyrocarbonate; RT-PCR: reverse transcription-polymerase chain reaction; EtBr: ethidium bromide; FW: tissue fresh weight.

\section{INTRODUCTION}

"The rose is a rose, and was always a rose. But now the theory goes that the apple's a rose, and the pear is, and so's the plum, I suppose.

The dear only knows what will next prove a rose..."

Robert Frost (Poem lyrics of the Rose Family)
Rosaceae (the rose family) includes economically important fruit crops such as apples (genus Malus), pears (genus Pyrus), raspberries/blackberries (genera Rubus), strawberries (genus Fragaria), and stonefruits such as peaches, plums, cherries, almonds, apricots (genus Prunus). Among the species within the Rosaceae family, it has been proposed that Prunus persica (peach) may serve as an ideal genomic model (Christensen, 2003; Georgi et al., 
2002; Sosinski et al., 2000). The characteristics of peach that make it a very interesting candidate as a genomic model are that it is a self-pollinating diploid $(2 n=16)$, has a small genome size of approximately $300 \mathrm{Mb}$ haploid size (approximately twice the size of Arabidopsis), and a relatively short juvenile stage for a perennial tree species (Arumuganathan and Earle, 1991; Baird et al., 1994; Georgi et al., 2002; Sosinski et al., 2000). Additionally, numerous efforts have been made to create tools to assist in developing peach as a genome model, and molecular markers, genetic linkage maps and BAC libraries have been developed (Dirlewanger et al., 1998; Georgi et al., 2002; Sosinski et al., 2000; Wang et al., 2002a, b).

To further develop peach as a genomic model, it is necessary to optimize protocols for isolating total RNA so that cDNA libraries may be constructed to identify EST sequences and to allow gene expression analyses to be performed to begin to analyze putative gene functions. To this end, we have compared the efficiency of three different protocols for RNA isolation. The first two protocols: (1) A phenol:chloroform extraction and $\mathrm{LiCl}$ precipitation protocol (Das et al., 1990) and (2) A guanidinium thiocyanate-phenol-chloroform extraction protocol (Chomczynski and Sacchi, 1987), resulted in total RNA that was contaminated with large quantities of polysaccharides and phenolic compounds as determined by spectrophotometer analyses. The third protocol (Peach protocol) is one that we have developed to optimize RNA isolation from peach fruits containing high levels of polysaccharides and poly-phenolic compounds. This protocol is a modification of several different RNA isolation protocols from plants. (Chang et al., 1993; Salzman et al., 1999; Zeng and Yang, 2002). The Peach protocol uses CTAB, high salt concentrations $\quad(\mathrm{NaCl}), \quad$ and polyvinylpyrrolidone (PVP40) (PVP is an antioxidant able to remove phenolic compounds). This protocol yields highquality total RNA from peach/nectarine fruits, suitable for functional genomics analyses such as RT-PCR analysis and cDNA library construction.

\section{MATERIALS AND METHODS}

\section{Plant material}

Prunus persica (O'Henry variety) fruits at four different post-harvest stages were collected, peeled, sliced in wedges, quickly frozen in liquid nitrogen, and stored at $80^{\circ} \mathrm{C}$ until further use.

\section{Solutions and reagents}

Solutions were treated with DEPC as described by Sambrook et al. (1989) and autoclaved. Tris- $\mathrm{HCl}(\mathrm{pH} 8.0)$, prepared with DEPC-treated water, was added to the appropriate solutions post-autoclaving.

- Extraction buffer: 2\% (w/v) CTAB, 2\% (w/v) PVP (mol wt 40,000), $100 \mathrm{mM}$ Tris- $\mathrm{HCl}$ (pH 8.0), 25 mM EDTA, $2 \mathrm{M}$ $\mathrm{NaCl}, 0.05 \%$ spermidine trihydrochloride, $2 \%$ ß-mercaptoethanol (added just before use).

- SSTE: $1 \mathrm{M} \mathrm{NaCl}, 0.5 \%$ SDS, $10 \mathrm{mM}$ Tris HCL (pH 8.0), 1 mM EDTA (pH 8.0)

- Chloroform-isoamyl alcohol (24:1, v/v)

- $10 \mathrm{M} \mathrm{LiCl}$

- Absolute Ethanol

- $70 \%$ Ethanol (in DEPC water)

\section{Peach Protocol for RNA isolation}

\section{Extraction \#1}

Preheat $10 \mathrm{~mL}$ extraction buffer to $65^{\circ} \mathrm{C}$ in a water bath. Using a mortar and pestle, grind $4 \mathrm{~g}$ of fruit mesocarp in the presence of liquid nitrogen. Quickly transfer the frozen powder to the warm extraction buffer. Mix completely by vortexing the tube. Incubate samples at $65^{\circ} \mathrm{C}$ for $15 \mathrm{~min}$. Be sure to vortex the sample several times during this incubation period to avoid separation of the tissue and extraction buffer. Add an equal volume of chloroform-isoamyl alcohol (24:1) and vortex vigorously. Centrifuge at $12,000 \mathrm{~g}$ for $20 \mathrm{~min}$., or longer if the phases are not clearly separated. Transfer the supernatant to a new tube; it will be very viscous at this stage. Re-extract the sample with an equal volume of chloroform-isoamyl 
alcohol. (24:1). Centrifuge as previously described. Carefully transfer the supernatant to a new tube. To ensure that high quality RNA is obtained, avoid transferring the interphase or chloroform. If problems arise, the samples can be centrifuged again as previously described.

Precipitation \#1:

Add 0.25 volumes of $10 \mathrm{M} \mathrm{LiCl}$ to the supernatant. Mix well by inverting the tube. Incubate samples overnight at $4^{\circ} \mathrm{C}$. Pellet the RNA by centrifuging the sample at $12,000 \mathrm{~g}$ for $35 \mathrm{~min}$ at $4^{\circ} \mathrm{C}$. Carefully discard the supernatant. Resuspend the pellet with $500 \mu \mathrm{l}$ SSTE. Transfer the resuspended pellet to a microfuge tube

\section{Extraction \#2:}

Extract the sample with an equal volume of chloroform:isoamyl-alcohol to further reduce contaminants. Vortex, centrifuge at $14,000 \mathrm{~g}$ for $10 \mathrm{~min}$ at $4^{\circ} \mathrm{C}$, and recover the aqueous phase.

Precipitation \#2:

Add 2 volumes of $100 \%$ ethanol to the sample. Precipitate the RNA at $-80^{\circ} \mathrm{C}$ for 30 min. Centrifuge at $14,000 \mathrm{~g}$ for $20 \mathrm{~min}$, at $4^{\circ} \mathrm{C}$. Discard the supernatant and wash pellet with $1 \mathrm{ml} 75 \%$ ethanol. Centrifuge at $14,000 \mathrm{~g}$ for $10 \mathrm{~min}$ at $4^{\circ} \mathrm{C}$. Remove supernatant and dry the pellet at room temperature. Dissolve the RNA in DEPCtreated water $(\mathrm{pH} 5.0)$. Store at $-80^{\circ} \mathrm{C}$ until future use.

Quantification and Quality Control

Calculate RNA quality and quantity spectrophotometrically by analyzing absorption ratios: A260/240 and A260/280. Absorption ratios A260/240 and A260/280 detect polysaccharide/polyphenolic contaminants and protein contaminates, respectively (Asif, 2000; Logemann et al., 1997; Manning, 1990). Confirm RNA quality by an EtBr stained $1.5 \%$ agarose gel containing $3 \%$ formaldehyde.

\section{$R T-P C R$}

cDNA synthesis was prepared using Revert Aid TM $H$ Minus M-MuLV Reverse
Transcriptase (MBI Fermenta) according to the manufacturer's specifications. RT-PCR amplifications were performed using actin specific primers designed using the nucleotide sequence of Prunus persica actin (Accession \# AB046952). The sequence of the actin forward primer is 5'gATTCTggTgATggTgTgAgTCA - 3'. The actin reverse primer is $5^{\prime}$ gAgAgATggCTggAAgAggACTT -3'. The PCR reaction was carried out for 40 cycles, under the following cycle conditions: denaturation at $94^{\circ} \mathrm{C}$ for 30 seconds, annealing at $55^{\circ} \mathrm{C}$ for 1 minute, and extension at $72^{\circ} \mathrm{C}$ for $1.5 \mathrm{~min}$. The final extension time was $10 \mathrm{~min}$ at $72^{\circ} \mathrm{C}$.

\section{Library Constructions}

mRNA isolated from the total RNA was reverse transcribed into cDNA. This cDNA was enriched for large fragments and subsequently cloned directionally into pDNR-1r vector (Clontech) at the XhoISmaI sites (Agencourt library construction service). The percentage of recombinants and the clone range of these libraries were analyzed by PCR analysis of 24 randomly selected clones (Agencourt library construction service).

\section{RESULTS AND DISCUSSION}

Studying gene expression in fruit trees can be technically complicated due to the large quantity of polysaccharides and polyphenolic compounds that accumulate during ripening and/or in response to environmental stimuli. These polysaccharides and polyphenolic compounds often co-precipitate and contaminate the RNA during the extraction, thereby affecting both the quality and quantity of RNA isolated (Asif et al., 2000; Logemann et al., 1987).

With the aim of developing Prunus persica as a genomic model for the family Rosaceae, we analyzed three different RNA isolation protocols using peach fruits (tissues that contain very high levels of polysaccharides and polyphenolic compounds). The first protocol uses commercially-available TRIzol (Gibco- 
BRL) according to manufacturer's specifications. This protocol is based upon a guanidinium thiocyanate-phenolchloroform extraction method originally described by Chomczynski and Sacchi (1987). The second protocol is based upon a phenol:chloroform extraction and $\mathrm{LiCl}$ precipitation protocol as describe by Das et al. (1990). These protocols have been used to isolate RNA from leaf tissue in model plants such as arabidopsis, tobacco and maize (Das et al., 1990; Meisel and Lam, 1996; Silva et al., 1999). However, use of such protocols on peach fruits yielded poor quality RNA with high levels of polysaccharides, polyphenolic compounds, and protein contaminants as determined by A240/260 and A260/280, respectively (Logemann et al., 1987; Manning 1990) (Table I).

Due to the high level of contaminants detected in the RNA isolated using the two previously described protocols, we developed an optimized RNA isolation protocol for peach fruits based on several protocols developed for isolating RNA from tissues containing high levels of polysaccharides and polyphenolic compounds such as grape berries, pine trees, and woody plants Cinnamomum tenuipilum (Chang et al., 1993; Salzman et al., 1999; Zeng and Yang 2002). The peach protocol consists of two extractions and two precipitation steps.

The first extraction is similar to the RNA isolation method for Cinnamomum tenuipilum described by Zeng and Yang (2002) and is performed in a buffer containing 2\% CTAB, $100 \mathrm{mM}$ Tris-HCL
(pH8.0), 25 mM EDTA, $2 \mathrm{M} \mathrm{NaCl}, 0.05 \%$ spermidine trihydrochloride and $2 \% \quad \beta-$ mercaptoethanol. However, the peach extraction buffer contains 2\% PVP, which has a molecular weight of 40,000, whereas the method by Zeng and Yang (2002) uses PVP (molecular weight 25,000). Following the first extraction, the RNA was precipitated using $\mathrm{LiCl}$, resuspended and transferred to a microfuge tube so a second extraction and precipitation could be performed efficiently, reducing the volume of reagents and time of extraction and precipitation.

Using the Peach protocol we obtained good RNA yield ( $24 \mu \mathrm{g} / \mathrm{g}$ FW) with low levels of polysaccharides, polyphenolic compounds and protein contaminants as determined by A240/260 and A260/280, respectively (Logemann et al., 1987; Manning 1990) (Table I). Furthermore, this RNA was not degraded, as was demonstrated by visualizing the ribosomal RNA of the samples on a denaturing $1.5 \%$ agarose $/ 1.1 \%$ formaldehyde gel (Ausubel et al., 1997; Fig. 1A). As seen in Figure 1A, four different RNA extractions from fruits at different stages post-harvest resulted in $28 \mathrm{~S}$ ribosomal RNA bands that are approximately twice as intense as the $18 \mathrm{~S}$ ribosomal RNA band. RT-PCR analysis of actin in these RNA extracts also demonstrated that there are no contaminants that interfere with reverse transcription or PCR reactions (Fig. 1B). The negative control for the RT-PCR reaction $\left(\mathrm{H}_{2} \mathrm{O}\right)$ did not show any amplification (data not shown).

TABLE I

Spectrophotometer analysis of the purity of RNA isolated from three different extraction protocols

\begin{tabular}{lccc}
\hline \multicolumn{1}{c}{ Protocols } & $\mathbf{A}_{\mathbf{2 6 0 / 2 4 0}}{ }^{*}$ & $\mathbf{A}_{\mathbf{2 6 0} / 280^{*}}$ & Yield( $\mu$ g RNA/ g FW) \\
\hline TRIzol & 0.6 & 1.4 & $22.5^{\dagger}$ \\
Phenol: Chloroform & 1.5 & 1.6 & $7^{\dagger}$ \\
Peach Protocol & $\mathbf{1 . 6}$ & $\mathbf{2 . 0}$ & $\mathbf{2 4}$ \\
\hline
\end{tabular}

* Results are expressed as the mean of three extractions

$\dagger$ Yield values are not accurate due to the low A260/A280 ratio 
The RNA isolated using the Peach method was also used to create four different cDNA libraries. As summarized in Table II, the RNA isolated using the peach method was successfully used in creating large-insert cDNA libraries with a high number of recombinants.

The analysis of the RNA quality by spectrophotometric analysis, agarose gel analysis of the intensity of the ribosomal RNAs, RT-PCR analysis, and the construction of four large-insert cDNA libraries demonstrate that the Peach RNA isolation protocol presented in this paper can be used to efficiently isolate high quality RNA with low levels of contaminants suitable for functional genomic analyses.

\section{ACKNOWLEDGEMENTS}

This research was supported by FDI G02P1001 (Chilean Genome Initiative), ASOEX (Asociación de Exportadores de Chile A.G.), FDF (Fundación para el Desarrollo Frutícola), Fundación Chile, and the Millenium Nucleus in Plant Cell Biology (P002-009-F).

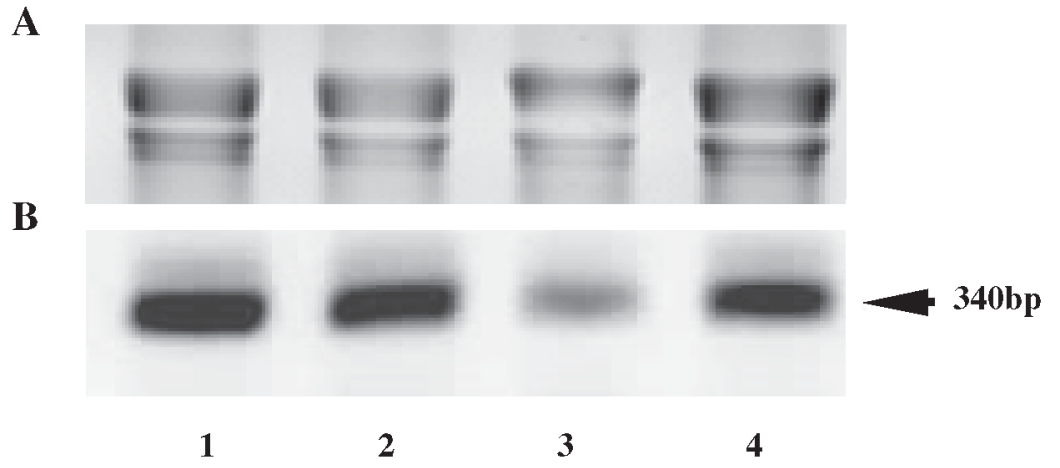

Figure 1. Peach extraction protocol yields high quality RNA as determined by agarose gel and RT-PCR analyses. (A) Total RNA isolated using the peach extraction protocol was separated on an denaturing $1.5 \%$ agarose $/ 1.1 \%$ formaldehyde gel and staining with ethidium bromide. (B) RT-PCR of actin transcripts from total RNA isolated using the peach extraction protocol. Lanes represent extraction from fruits at four different stages post-harvest.

TABLE II

Quality of cDNA libraries constructed using RNA isolated by the peach extraction protocol

\begin{tabular}{ccc}
\hline Library & \% Recombination & Clone range \\
\hline 1 & 92 & $0.8-2.6 \mathrm{~Kb}$ \\
2 & 96 & $0.7-2.2 \mathrm{~Kb}$ \\
3 & 96 & $0.7-3.0 \mathrm{~Kb}$ \\
4 & 100 & $0.7-2.9 \mathrm{~Kb}$ \\
\hline
\end{tabular}




\section{REFERENCES}

ARUMUGANATHAN K, EARLE ED (1991) Nuclear DNA content of some important plant species. Plant Mol Biol Rep 9(3): 208-218

ASIF MH, DHAWAN P, NATH P (2000) A simple procedure for the isolation of high quality RNA from ripening banana fruit. Plant Mol Biol Rep 18: 109-115

AUSUBEL FM, BRENT R, KINGSTON RE, MOORE DD, SMITH JA, SEIDMAN JG, STUHL K (1997) Current Protocols in Molecular Biology. New York: John Wiley and Sons

BAIRD WV, ESTAGER AS, WELLS JK (1994) Estimating nuclear DNA content in peach and related diploid species using laser flow cytometry and DNA hybridization. J Am Soc Hort Sci 119: 1312-1316

CHANG S, PURYEAR J, CAIRNEY J (1993) A simple method for isolating RNA from pine trees. Plant Mol Biol Rep 11: 113-116

CHOMCZYNSKI P, SACCHI N (1987) Single-step method of RNA isolation by acid guanidinium thiocyanate-phenolchloroform extraction. Anal Biochem 162: 156-159

CHRISTENSEN D (2003) Fruit genome projects ripen on the vine. Nature Med 9:250

DAS OP, ÁLVAREZ C, CHAUDHURI S, MESSING J (1990) Molecular methods for genetic analysis of maize. Methods Mol Cell Biol 1: 213-222

DIRLEWANGER E, PRONIER V, PARVERY C, ROTHAN C, GUYE A, MONET R (1998) Genetic linkage map of peach [Prunus persica (L.) Batsch] using morphological and molecular markers. Theor Appl Genet 97: 888-895

GEORGI LL, WANG Y, YVERGNIAUX D, ORMSBEE T, IÑIGO M, REIGHARD G, ABBOTT AG (2002) Construction of a BAC library and its application to the identification of simple sequence repeats in peach [Prunus persica (L.) Batsch]. Theor Appl Genet 105: $115-1158$
LOGEMANN J, SCHELL J, WILLMITZER L (1987) Improved method for the isolation of RNA from plant tissues. Anal Biochem 163: 16-20

MANNING K (1990) Isolation of nucleic acids from plants by differential solvent precipitation. Anal Biochem 195: 45-50

MEISEL L, LAM E (1996) The conserved ELKhomeodomain of KNOTTED-1 contains two regions that signal nuclear localization. Plant Molecular Biology 30: 1-14

SALZMAN RA, FUJITA T, ZHU-SALZMAN K, HASEGAWA PM, BRESSAN RA (1999) An improved RNA isolation method for plant tissues containing high levels of phenolic compounds or carbohydrates. Plant Mol Biol Rep 17: 11-17

SAMBROOK J, FRITSCH EF, MANIATIS T (1989) Molecular Cloning a Laboratory Manual, $2^{\text {nd }}$ ed. New York: Cold Spring Harbor Laboratory Press. pp: 7.3-7.4

SILVA H, YOSHIOKA K, DOONER HK, KLESSIG DF (1999) Characterization of a new Arabidopsis mutant exhibiting enhanced disease resistance. MPMI 12:1053-1063

SOSINSKI B, GANNAVARAPU M, BECK LE, RAJAPAKSE S, BALLARD RE, ABBOTT AG (2000) Characterization of microsatellite markers in peach [ Prunus persica (L.) Batsch]. Theor Appl Genet 101:421-428

WANG Y, GEORGI LL, ZHEBENTYAYEVA TN, REIGHARD GL, SCORZA R, ABBOTT AG (2002a) High-throughput targeted SSR marker development in peach (Prunus persica). Genome 45: 319-328

WANG Y, GEORGI LL, REIGHARD GL, SCORZA R, ABBOTT, AG (2002b) Genetic Mapping of the evergrowing Gene in Peach [Prunus persica (L.) Batsch]. J Heredity 93(5):352-358

ZENG Y, YANG T (2002) RNA isolation from highly viscous samples rich in polyphenols and polysaccharides. Plant Mol Biol Rep 20: 417a-417e. 